\title{
Numerical Control Simulation and Experimental Study on End Milling Ordinary Cycloidal Gear in Five-axis CNC Machine Tool
}

Jianmin Xu, Shanming Luo, Shui xuan Chen

School of Mechanical and Automotive Engineering, Xiamen University of Technology, Xiamen 361024. China. Email:xujianmin1020@163.com,smluo@xmut.edu.cn, csx@xmut.edu.cn

\begin{abstract}
A machining method of end milling cycloidal gear using ball end mill is proposed based on the analysis of grinding and side milling ordinary cycloid gear. The machining principle of end milling cycloid gear using 5-axis CNC milling machine is analyzed and the geometric model of end milling cycloid gear is established. At the same time the NC simulation of the machining process is conducted. End milling ordinary cycloid gear is conducted using five-axis machining center and it verifies the feasibility and scientific of end milling ordinary cycloidal gear. The machining precision of the cycloid gear is measured using a three coordinate measuring machine, and it verifies the reliability and usefulness of the machining method. It proves that the machining method can achieve grinding precision. Using end milling instead of grinding cycloid gear is achieved in order to improve the machining efficiency.
\end{abstract}

Keywords: ordinary cycloid gear; end milling; five-axis CNC machining; measuring accuracy

\section{Acknowledgement}

This paper is supported by the National Natural Science Foundation of China (Grant No. 51375411; 51205336).

\section{References}

[1] WANG, W S, FONG, Z H. (2008). A dual face-hobbing method for the cycloidal crowning of spur gears. Mechanism and Machine Theory, 43(11), 1416-1430.

[2] WANG, W S, FONG, Z H. (2011). Undercutting and contact characteristics of longitudinal cycloidal spur gears generated by the dual face-hobbing method. Mechanism and Machine Theory, 46(4),399-411.

[3] WANG, S., TIAN, G., JIANG, X. (2012). Estimation of Sliding Loss in a Cycloid Gear Pair. International Journal of Advancements in Computing Technology, 4(20),124-132.

[4] LIU, J., CHEN, B., MATSUMURA, S., LI, C., HOUJOH, H. (2012). Design of a Novel Cycloid Drive with a Cycloid-arc Gear and Analysis of Its Meshing Characteristic. Journal of Advanced Mechanical Design, Systems, and Manufacturing, 6(2), 310-322.

[5] GUAN, T. M., LI, J. B., LEI, L. (2013). Tooth Surface Contact Fatigue Reliability Analysis of Cycloidal Gear Based on Monte-Carlo. In: Advanced Materials Research,605, ,811-814.

[6] CHEN, B., ZHONG, H., LIU, J., LI, C., FANG, T. (2012). Generation and investigation of a new cycloid drive with double contact. Mechanism and Machine Theory, 49, 270-283.

[7] SONG, Y., LIAO, Q., WEI, S., GUO, L., SONG, H., LIFENG, Z. (2014). Modelling, simulation and experiment of a novel pure rolling cycloid reducer with involute teeth. International Journal of Modelling, Identification and Control, 21(2), 184-192.

[8] YIN, D. Q., WANG, J. W., ZHAO, Y. (2014). Automatic Corn Potted-Seedling Transplanter of Cycloid Gear Trains. Applied Mechanics and Materials, 530, 960-966.

[9] HSIEH, C. F. (2015). Traditional versus improved designs for cycloidal speed reducers with a small tooth difference: The effect on dynamics. Mechanism and Machine Theory, 86, 15-35.

[10] LEI, L., SHI, X. C., GUAN, T. M. (2012). Finite Element Analysis for Cycloid Gear and pin Teeth of FA Cycloid Drive Based on ANSYS. Applied Mechanics and Materials, 215, 1197-1200.

[11] JIANG, Z. Z. (2014). Cycloid Pinwheel Planet Drive Nonlinear Meshing Stiffness Calculation and Analysis. Applied Mechanics and Materials, 543, 224-227.

[12] SHAN, C. J., BIAN, Y. D., LI, L. (2014). Part Design and Analysis of Cycloid Installation Systems. In Applied Mechanics and Materials,539, 51-54. 
[13] LU, X. C. (2013). Minimum Sensitivity Robust Design of Cycloid Pinwheel Speed Reducer. In Applied Mechanics and Materials, 251, 279-282.

[14] XUAN, L., LEI, L., GUAN, T. M., LI, J. B. (2013). The Transmission Precision Test Research of High Precision FA45-29 Prototype. Applied Mechanics and Materials, 328, 376-381.

[15] CAROU, D., ŘEHOŘ, J., MONKA, P., VILČEK, I., HOUDKOVÁ, Š. (2015). Insights for the Selection of the Machining Parameters in the Turning of Difficult-To-Cut Coatings. MANUFACTURING TECHNOLOGY, 15 (3), 295-303.

[16] SEDLAK, J., TROPP, P., CHLADIL, J., OSICKA, K., SLIWKOVA, P. (2015). High-Speed Cutting of Bearing Rings from Material 100Cr6. MANUFACTURING TECHNOLOGY, 15 (5), 899-908.

[17] IZOL, P., FABIAN, M., KOPAS, M., FEDORKO, G., FABIANOVA, J. (2014). Evaluation of Surface Milling Strategies Using Selected Elements of Machined Shapes of Forging Die Cavities. MANUFACTURING TECHNOLOGY. 14 (2), 178-185.

[18] BILEK, O., VASINA, M. (2014). CNC Milling and Manufacturing of Groove Shapes for Light Reflection Measurement. MANUFACTURING TECHNOLOGY, 14, (4)516-522. 